\title{
Altered immune status of circulating $T$ lymphocytes during sepsis: children also
}

\author{
Jean-Marc Cavaillon \\ See related research by Muszynski et al., http://ccforum.com/content/18/4/R145
}

\begin{abstract}
Altered immune status of blood leukocytes is a general phenomenon observed in adult patients with sepsis or septic shock. This is also the case in children with septic shock for both T helper 1 and T helper 2 lymphocytes, as demonstrated by their reduced ex vivo cytokine production upon activation by phytohemagglutinin.
\end{abstract}

In a recent paper published in Critical Care, Muszynski and colleagues [1] report that, in children with septic shock, purified blood CD4+ T lymphocytes display an altered responsiveness to a non-specific mitogen (phytohemagglutinin A (PHA)) as assessed by reduced production of IL-2, interferon (IFN)- $\gamma$, IL-4 and IL-10. They also showed that lipopolysaccharide (LPS)-induced TNF is decreased, and that the percentage of circulating regulatory $\mathrm{T}$ lymphocytes (Tregs) is unchanged.

This is probably the first study establishing that in children, as in adults, the immune status of circulating CD4+ T lymphocytes is altered in terms of cytokine production. The early demonstration of an altered T-cell response in adult patients with sepsis was reported in 1977, when a significant reduced delayed-type hypersensitivity to recall antigens was observed [2]. Unfortunately, other functional tests to precisely assay the adaptive responsiveness of $\mathrm{T}$ cells (for example, response to antigens, specific cytotoxicity, and so on) are scarce.

Different observations in Muszynski and colleagues' study are of interest. First, the authors report that the mortality was only $9 \%$, a value far below that regularly reported for adults with septic shock [3]. This low percentage of deceased children is in agreement with the known low mortality rates in children for several

Correspondence: jean-marc.cavaillon@pasteur.fr

Unité Cytokines \& Inflammation, Institut Pasteur, 28 Rue Dr. Roux, 75014 Paris, France (Th)1 (IFNy, IL-2) or Th2 (IL-4, IL-10) cytokines. This is against the dogma claiming that sepsis is associated with an up-regulation of the Th2 response and a downregulation of the Th1 response. However, this fits with a previous study in adults with sepsis or non-infectious systemic inflammatory response syndrome (SIRS) [6], and with another report in trauma patients [7] in whom production of both ex vivo Th1 and Th2 cytokines was altered. Furthermore, the authors showed that the decreased capacity of CD4+ T lymphocytes to produce cykines was transient and normal responsiveness was tored by day 7. A similar observation was made for 7 except in the two non-surviving children. This is surviving patients [8].

It is worth mentioning that circulating lymphocytes have been shown not to be the main leukocyte population with altered gene profiles during septic shock. Indeed, in pediatric septic shock, Wong and colleagues [9] showed that 109 genes were up- or down-regulated in all types of lymphocytes, whereas 965 genes in monocytes, and 2,360 genes in neutrophils were modulated. hether this observation reflects enhanced apoptosis of lymphocytes in sepsis compared with other leukocytes remains to be fully examined. Great differences in 
transcriptomic response according to developmental age were noted in children with septic shock [10]. Because of the small number of children included in the study, the authors could not determine whether the observed alteration was identical in neonates, infant and schoolage children.

The authors made their observation using PHA; surprisingly, in a study performed in adult sepsis a similar observation could not be achieved with this mitogen but only with concanavalin A [6]. This difference may be explained by different parameters of the experimental procedure (length of incubation, whole blood versus purified T-cell subset, addition of fetal bovine proteins, and so on). Because PHA response is due to a T-cell subset [11], and is mainly dependent on accessory cells $[12,13]$, one cannot exclude that the observation also partially reflects an altered cooperative role of accessory cells (monocytes, dendritic cells). The median percentage purity of CD4+ cells was $93 \%$. Since as little as $0.03 \%$ adherent cells are sufficient to allow PHAinduced proliferation by purified $\mathrm{T}$ cells [14], a sufficient number of accessory cells were still present to allow the PHA-induced cytokine production. Anyhow, other authors who employed anti-CD3 plus anti-CD28 coated beads or plates to bypass the need for accessory cells and to target all CD4+ and CD8+ T lymphocytes made similar conclusions regarding the immune status of $\mathrm{T}$ lymphocytes in adult patients with sepsis $[15,16]$.

In addition, the authors analyzed the presence of circulating Treg cells, and found an unchanged percentage. In this context it is worth mentioning that, at homeostasis, a balance exists between IL-2 producer cells and Tregs, which sepsis most probably disrupts [17]. In contrast, in adult sepsis the percentage of circulating Tregs is enhanced but their absolute number is roughly unchanged compared with healthy volunteers as a reflection of the global lymphopenia [18]. Finally, and most importantly, it is worth recalling that the immune status of $\mathrm{T}$ lymphocytes in tissues might be completely different to that revealed by the analysis performed in the blood stream after sepsis or sterile SIRS $[19,20]$.

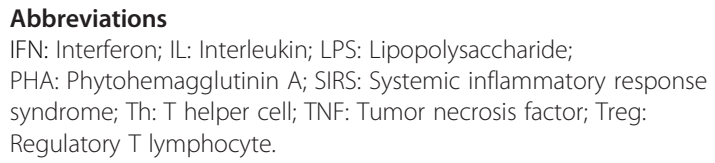

Competing interests

The author declares that he has no competing interests.

Published online: 14 August 2014

\section{References}

1. Muszynski J, Nofziger R, Greathouse K, Steele L, Hanson-Huber L, Nateri J, Hall M: Early adaptive immune suppression in children with septic shock: a prospective observational study. Crit Care 2014, 18:R145.
2. Meakins JL, Pietsch JB, Bubenick O, Kelly R, Rode H, Gordon J, MacLean LD: Delayed hypersensitivity: indicator of acquired failure of host defenses in sepsis and trauma. Ann Surg 1977, 186:241-250.

3. Annane D, Bellissant E, Cavaillon JM: Septic shock. The Lancet 2005, 365:63-78.

4. Fedson DS: Treating influenza with statins and other immunomodulatory agents. Antiviral Res 2013, 99:417-435.

5. Motegi A, Kinoshita M, Sato K, Shinomiya N, Ono S, Nonoyama S, Hiraide H, Seki S: An in vitro Shwartzman reaction-like response is augmented agedependently in human peripheral blood mononuclear cells. J Leukoc Biol 2006, 79:463-472.

6. Muret J, Marie C, Fitting C, Payen D, Cavaillon J-M: Ex vivo T-lymphocyte derived cytokine production in SIRS patients is influenced by experimental procedures. Shock 2000, 13:169-174.

7. De AK, Kodys KM, Pellegrini J, Yeh B, Furse RK, Bankey P, Miller-Graziano CL: Induction of global anergy rather than inhibitory Th2 lymphokines mediates post-trauma T-cell immunodepression. Clin Immunol 2000, 96:52-66.

8. Muñoz C, Carlet J, Fitting C, Misset B, Bleriot JP, Cavaillon JM: Dysregulation of in vitro cytokine production by monocytes during sepsis. J Clin Invest 1991, 88:1747-1754.

9. Wong HR, Freishtat RJ, Monaco M, Odoms K, Shanley TP: Leukocyte subsetderived genome-wide expression profiles in pediatric septic shock. Pediatr Crit Care Med 2010, 11:349-355.

10. Wynn JL, Cvijanovich NZ, Allen GL, Thomas NJ, Freishtat RJ, Anas N, Meyer K, Checchia PA, Lin R, Shanley TP, Bigham MT, Banschbach S, Beckman E, Wong HR: The influence of developmental age on the early transcriptomic response of children with septic shock. Mol Med 2011, 17:1146-1156.

11. Schwartz JL, Darr JC, Gaulden ME: Survival and PHA-stimulation of gamma-irradiated human peripheral blood T lymphocyte subpopulations. Mutat Res 1983, 107:413-425.

12. Ulmer AJ, Scholz W, Ernst M, Flad HD: Response of human T lymphocytes to phytohemagglutinin $(\mathrm{PHA})$ after sequential depletion of monocytes, HLA-DR+, Leu11a+, and Leu7+ cells. Immunobiology 1985, 170:419-433.

13. Ceuppens JL, Baroja ML, Lorre K, Van Damme J, Billiau A: Human T cell activation with phytohemagglutinin. The function of IL-6 as an accessory signal. J Immunol 1988, 141:3868-3874.

14. Chu E, Gesner M, Gorga J, Geha RS: Role of la antigens and interleukin 1 in T-cell proliferation to phytohemagglutinin. Clin Immunol Immunopathol 1985, 36:70-80.

15. Venet F, Foray AP, Villars-Mechin A, Malcus C, Poitevin-Later F, Lepape A, Monneret G: IL-7 restores lymphocyte functions in septic patients. J Immunol 2012, 189:5073-5081.

16. Boomer JS, Shuherk-Shaffer J, Hotchkiss RS, Green JM: A prospective analysis of lymphocyte phenotype and function over the course of acute sepsis. Crit Care 2012, 16:R112.

17. Almeida AR, Amado IF, Reynolds J, Berges J, Lythe G, Molina-Paris C, Freitas AA: Quorum-sensing in CD4(+) T cell homeostasis: a hypothesis and a model. Front Immunol 2012, 3:125.

18. Monneret G, Venet F, Pachot A, Lepape A: Monitoring immune dysfunctions in the septic patient: a new skin for the old ceremony. Mol Med 2008, 14:64-78.

19. Nüssler NC, Stange B, Nussler AK, Settmacher U, Langrehr JM, Neuhaus $P$, Hoffman RA: Upregulation on intraepithelial lymphocyte function in the small intestinal mucosa in sepsis. Shock 2001, 16:454-458.

20. Wang W, Smail N, Wang P, Chaudry $\mid \mathrm{H}$ : Increased gut permeability after hemorrhage is associated with upregulation of local and systemic IL-6. J Surg Res 1998, 79:39-46.

doi:10.1186/s13054-014-0486-0

Cite this article as: Cavaillon: Altered immune status of circulating T lymphocytes during sepsis: children also. Critical Care 2014 18:486. 